\title{
Preservation of Haemal Nodes Fixed by Means of Two Different Aldehyde Fixatives: a Scanning Electron Microscopic Study
}

\author{
Preservación de Nodos Linfáticos Hemales Fijados por Dos Fijadores de \\ Aldehído Diferentes: un Estudio de Microscopía Electrónica de Barrido
}

"Guerrero, F.; ** Cerutti, P. \& ** Marcaccini, A.

GUERRERO, F.; CERUTTI, P. \& MARCACCINI, A. Preservation of haemal nodes fixed by means of two different aldehyde fixatives: a scanning electron microscopic study. Int. J. Morphol., 29(2):656-660, 2011.

SUMMARY: Glutaraldehyde is the fixative most commonly used in electron microscope studies of biological tissues, however it is often necessary to use samples which were not fixed in this fixative, even with the usual uncertainty of the results that may be obtained. The fixation is the more delicate step of the sample processing. Therefore in this work, the quality of preservation of haemal nodes fixed with two classic aldehyde fixatives: formaldehyde and glutaraldehyde we have compared under the scanning electron microscope. Our results showed that both fixatives were successful in preserving the morphology of haemal nodes components; however glutaraldehyde conferred satisfactory results mainly in the preservation of parenchymal cells, whereas formaldehyde was better for preservation of stromal fibres.

KEY WORDS: Scanning electron microscopy; Fixation; Fixative; Haemal node; Glutaraldehyde; Formaldehyde.

\section{INTRODUCTION}

The parenchyma of haemal nodes is composes of nodes and cords of lymphocytes and macrophages. They are rounded by a connective capsule with preponderance of collagen fibres and an internal network of collagen and reticular fibres define their fine stroma. Haemal nodes develop different functions, including erythrophagocytosis, erythropoiesis, platelet formation, and immunological functions (Turner, 1971; Cecarelli et al., 1986; Cerutti \& Guerrero, 2001; Cerutti \& Guerrero, 2008). To understand and research these complex functions, it is first necessary to properly interpret their three-dimensional organization, and therefore is essential in achieving excellent sample preservation to carry out their study under the scanning electron microscope (SEM). The SEM is a useful tool for the morphological study of different organs and structures. Its principal advantage is the possibility of working on a wide area, aiming at the architectural evidence, both of the cellular groups and of a single cellular element (Balbi et al., 2009). Unfortunately, morphological details are often obscured as a result of poor preservation and by the artifacts produced by preparative techniques. The successful procedure of sample preparation remains a limiting factor in the quality of information provided by SEM; and the fixation process is one of the more delicate steps of this procedure.

One purpose of fixation is to maintain cells as close as possible to their original in vivo condition with regard to volume and morphology. Currently, there are different types of fixatives that can be used to SEM. In a recent study, it was established that ethanol-based fixative conferred a good preservation of the morphologic details of samples (Balbi et al., 2009); however most commonly used are those based on aldehyde fixatives and, of these, glutaraldehyde alone or mixed is mainly used. In this way, the choice of the suitable fixative depends not only on a fixed structure but also in the type of study that is performed.

The sample preparation for SEM studies causes serious artifacts not only in the compact tissues but also in hollow structures like the eye (Virtanen et al., 1984; Doughty et al., 1995; Doughty et al., 1997; Schraufnagel \& Schmid, 1998). Previous works have shown the effect of the fixative

* Departamento de Anatomía y Producción Animal. Facultad de Veterinaria. Universidad de Santiago de Compostela, España.

${ }^{* *}$ Cátedra de Histología II y Embriología Especial. Facultad de Ciencias Veterinarias. Universidad Nacional de Rosario, Argentina. 
process using aldehydes (glutaraldehyde and formaldehyde) in organs with hollows in their structure (Doughty et al., 1995, 1997; Schraufnagel \& Schmid), as well as in the preservation of the filaments (Bell et al., 1988), preservation of surface details (Osborne \& Comis, 1991) or preservation of nematodes parasites (Eisenback, 1986). However, in most of these publications the authors compared the use of glutaraldehyde alone, or in combination with formaldehyde, but in neither case formaldehyde was used alone as a fixative to preserve samples by SEM studies. Due to the significance of the information above, in this work we have compared, the quality of fixation of haemal nodes fixed with two aldehydes fixatives: formaldehyde alone and glutaraldehyde under the scanning electron microscope.

\section{MATERIAL AND METHOD}

For this study we used ten haemal nodes from healthy "manchega" breed sheep. The samples were removed from the mesenteric region using tweezers and scalpel. Five haemal nodes were fixed in $10 \%$ formaldehyde buffered with bisodium phosphate anhydrous and monohydrated monosodium phosphate, $\mathrm{pH} 7.4$ and 488 mOsm during 24 hours. The other five samples were fixed in $2.5 \%$ glutaraldehyde solution in cacodylate buffer 0.025 M, containing sucrose at $\mathrm{pH} 7.00$ and $435 \mathrm{mOsm}$, during 24 hours. The samples were not postfixed. The last procedure of fixation was carried out five times. The samples preserved in each fixative were cut in pieces according to different macroscopic regions of haemal node, and then were rinsed in cacodylate buffer $0.025 \mathrm{M}$, dehydrated in an ethanol series, critical-point dried and coated with gold. Afterwards the samples were examined under SEM.
The parameters used to evaluate the effectiveness of the fixatives employed were: a good preservation of cell shape (no cell shrinkage or swelling), and a good preservation of stromal fibrillar components. Of these latter, the shape (not broken) and organization (not showing large gaps between them, which may indicate alteration of their structural ordering) were evaluated.

\section{RESULTS}

The aldehyde fixatives were evaluated on the basis of the final image obtained with the SEM from the parenchymal cells and stromal fibres. The quality of fixation of the haemal nodes and the interaction of electron beam with the structures of the organ were the most important factors affecting the final image.

The three dimensional organization of haemal nodes was certainly recognized under SEM. Thus, we were able to successfully evaluate the structural elements of the parenchyma (lymph nodes and medullary cords) and stroma (capsule, sinus and cyto-reticulum) of the organ, and thereby to compare the effectiveness of both aldehyde fixatives.

Although both fixatives were successful in preserving the morphology of haemal nodes structures, we observed significant differences in the quality of fixation. Glutaraldehyde fixative was better for parenchymal cells preservation; maintaining both texture and turgency, without modification of their dimensions and morphology (Figs.1A, 1B). In relation to the action of glutaraldehyde fixative over the fibrillar components, even though their preservation was adequate, a loss of compactness with diffuses limits was observed (Fig. 1B).

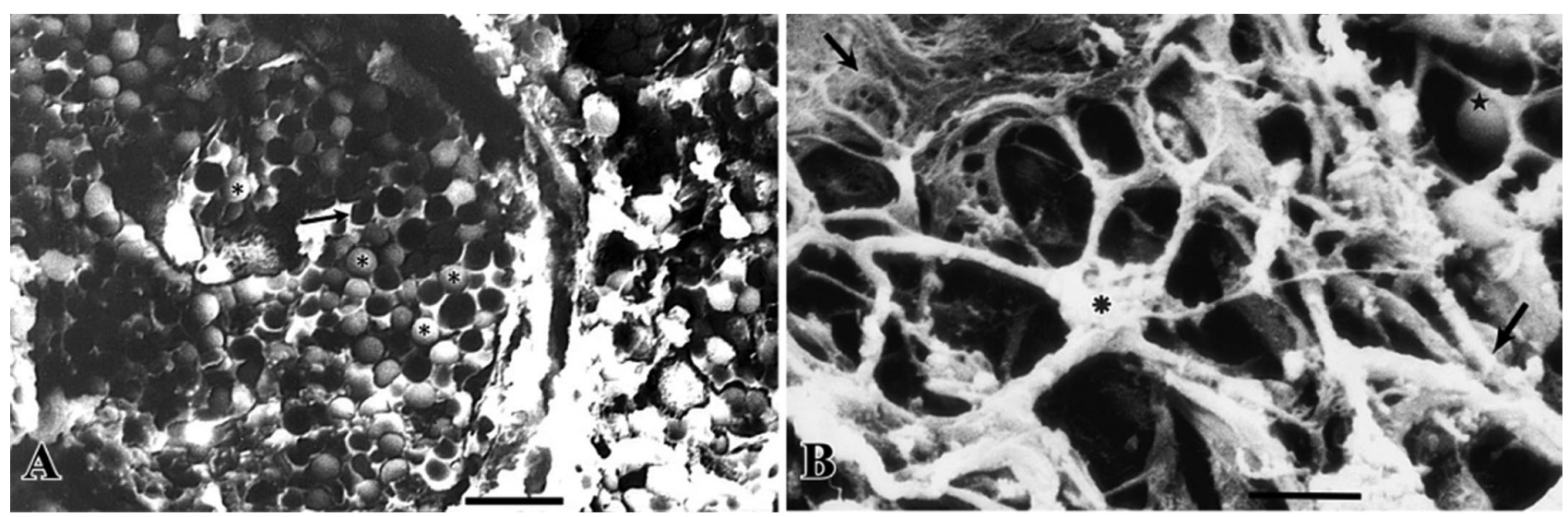

Fig. 1A. Lymph nodes in a cortex of haemal node fixed with glutaraldehyde fixative. Morphology of parenchymal cells is well preserved; maintained both texture and turgency (asterisks). In this case, the preservation of cyto-reticulum is adequate (arrow) $(\mathrm{bar}=10 \mu \mathrm{m})$. Fig. 1B. Subcapsular sinus of haemal node fixed with glutaraldehyde fixative. Preservation is poor and fine precipitations cover surface of collagen and reticular fibres (arrows). In the centre of picture a dendritic cell with diffuser limits is observed (asterisk). The star showed a lymphocyte well preserved $($ bar $=5 \mu \mathrm{m})$. 
On the other hand, the formaldehyde fixative showed better results in the preservation of the stroma constituents. They were observed building a fibrillar-compact structure in the capsule, with net limits. Likewise, the fibrillar labyrinth of the sinus and cyto-reticulum showed net limits and their shape and organization were properly preserved (Fig. 2A). Nevertheless, parenchymal cells were misshaped acquiring irregular contours and atypical morphology (Fig. 2B).

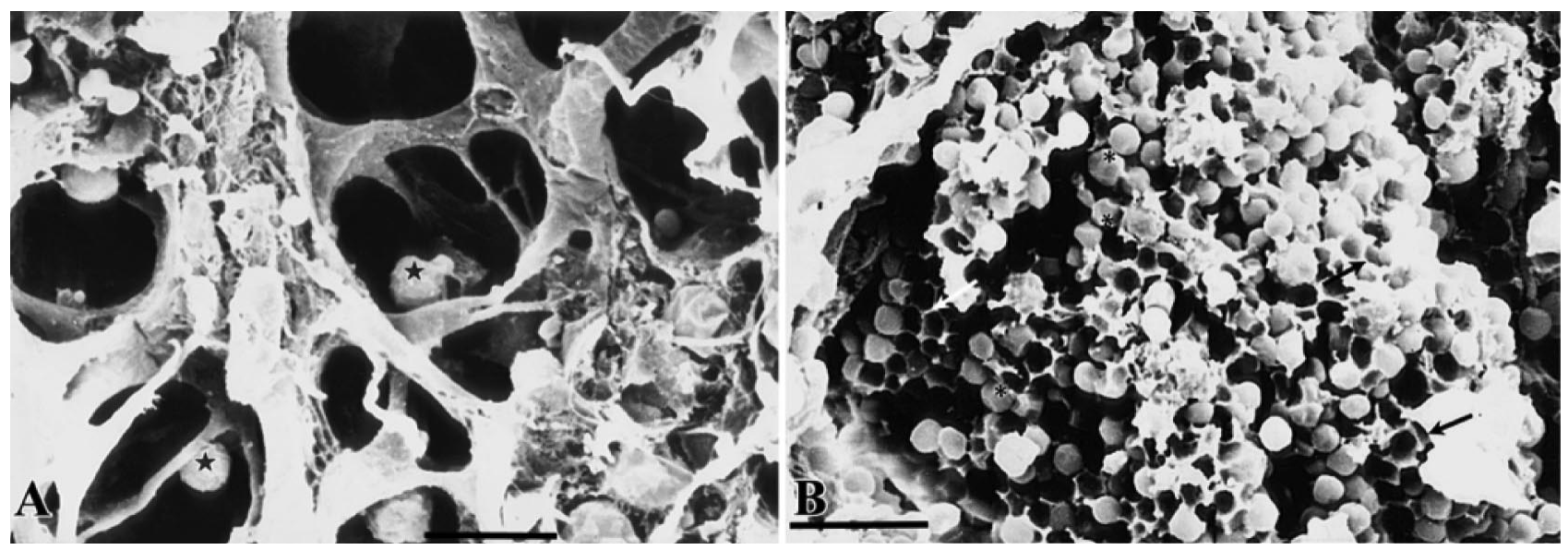

Fig. 2A. Medullar sinus of haemal node fixed with formaldehyde fixative. The fibrillar labyrinth showed net limits and their morphology is accurately conserved. Furthermore, poor preservation of circulating cells is observed (stars) $(\mathrm{bar}=10 \mu \mathrm{m})$.

Fig. 2B. Lymph nodes in a cortex of haemal node fixed with formaldehyde fixative. The preservation of cyto-reticulum is suitable (arrow), but parenchymal cells are misshaped and with atypical morphology (asterisks) $(\mathrm{bar}=10 \mu \mathrm{m})$.

\section{DISCUSSION}

The routine and scientific works in histology and histopathology laboratories become necessary to keep the structures of the samples in the best conditions for their observation and research. Although, there are several methods that have been adapted for studies on the mechanisms of fixation, in this study, we have evaluated under SEM the effects of formaldehyde fixative on the morphological appearance of cells and tissues of haemal nodes, compared with the same effects of glutaraldehyde, the fixative most commonly used in electron microscopy studies.

The type of fixative used for primary fixation of protein molecules was critical to the suitable preservation of samples and, although both fixatives were successful, glutaraldehyde conferred satisfactory results mainly in the preservation of parenchymal cells, whereas formaldehyde was better for preservation of stromal fibres.

Different reports referred that the best techniques of fixation for SEM are those that preserve the delicate surface of structures as apical blebs and microvilli; however like other authors, we assume that the fixation of tissues for SEM induce serious artefacts, and that these artefacts could to hinder the correct interpretation of results (Schook, 1980; Virtanen et al.).
Schook showed that using a fixation procedure which showed good results in the transmission electron microscopy, certain alterations had occurred in the samples processed with SEM. These alterations were brought about by some step specific to the processing, possibly related with osmolality of the fixative vehicle. In this sense, the osmotic pressure of the fixative must be carefully observed, since plasma membrane is especially sensitive to conditions of fixation and the osmolality of fixatives (Penttila et al., 1974; Stoffel et al., 1993). The high osmolality of chemical fixatives can produce changes in the organization of cells as well as distortion and cell shrinkage (Doughty et al., 1995, 1997). This seems to be corroborated by the results obtained in this study since formaldehyde, the fixative of higher osmolality, led to increased shrinkage and distortion of parenchymal cells. Our results are in agreement with those described by Eisenback, who observed nematodes with morphology altered mainly due to cell shrinkage induced by the use of formaldehyde alone as fixative. On the other hand, on contrary to that proposed by Eisenback, we consider that this fixative may be useful in certain histologycal studies since it adequately preserves the stroma constituents.

Although glutaraldehyde is the fixative most commonly used for the study of cell ultrastructure in 
biological tissues (Bullock, 1984), the results obtained in our study related with the fixation in formaldehyde could be useful mainly in histology or pathology laboratories in which the samples are routinely fixed in this fixative. Therefore, it is sometimes is necessary to investigate or to review more extensively a diagnostic or experimental study and, in the absence of new material, the samples stored should be used.

In view of our results, we can say that it is possible to recover samples fixed in formaldehyde fixative for routine SEM studies, especially when they do not involve detailed studies on the accurate preservation of cell morphology.

GUERRERO, F.; CERUTTI, P. \& MARCACCINI, A. Preservación de nodos linfáticos hemales fijados por dos fijadores de aldehído diferentes: un estudio de microscopia electrónica de barrido. Int. J. Morphol., 29(2):656-660, 2011.

RESUMEN: El glutaraldehido es el fijador que se utiliza con más frecuencia en estudios en los tejidos biológicos a través microscopía electrónica. Sin embargo, a menudo es necesario utilizar muestras que no han sido fijadas con este fijador, aún con la incertidumbre de los resultados que se puedan obtener. La fijación es el paso más importante en el procesamiento de los tejidos. Por lo anterior, hemos efectuado este estudio comparando la calidad de conservación de nodos linfáticos hemales fijados con formaldehido y glutaraldehido. Los resultados muestran que ambos fijadores conservaron adecuadamente la morfología de los componentes de los nodos linfáticos hemales, sin embargo, el glutaraldehido conservó en mejores condiciones, principalmente, las células del parénquima, pero el formaldehido conservó mejor las fibras del estroma en nodos linfáticos.

PALABRAS CLAVE: Microscopía electrónica de barrido; Fijación; Fijador; Nodo linfático hemal; Glutaraldehído; Formaldehído.

\section{REFERENCES}

Balbi, T.; Cicognani, A.; Esposti, P. D. \& Pierini, G. Microwave processing and ethanol-based fixation in forensic pathology: an addendum of further scanning electron microscope observations. Am. J. Forensic Med. Pathol., 30(3):242-5, 2009.

Bell, P. B. Jr.; Lindroth, M. \& Fredriksson, B. A. Preparation of cytoskeletons of cells in culture for high resolution scanning and scanning transmission electron microscopy. Scanning Microsc., 2(3):1647-61, 1988.

Bullock, G. R. The current status of fixation for electron microscopy: a review. J. Microsc., 133:1-15, 1984.

Cecarelli, P.; Gargiulo, A. M.; Fagioli, O. \& Pedini, V. Cytochemical identification of lymphocytes and other mononuclear cells in bovine haemal nodes. Com. Immunol. Microbiol. Dis., 9(4):297-302, 1986.

Cerutti, P. \& Guerrero, F. Erythropoiesis and erythrophagocytosis in bovine haemal nodes. Int. J. Morphol., 26(3):557-62, 2008.

Cerutti, P. \& Guerrero, F. Identification of positive cells to interleukin-4 in bovine haemal nodes. Anat. Histol. Embryol., 30(4):219-23, 2001.

Doughty, M. D.; Bergmansont, J. P. \& Blocker, Y. Impact of glutaraldehyde versus glutaraldehyde-formaldehyde fixative on cell organization in fish corneal epithelium. Tissue Cell, 27(6):701-12, 1995.

Doughty, M. J.; Bergmanson, J. P. \& Blocker, Y. Shrinkage and distortion of the rabbit corneal endothelial cell mosaic caused by a high osmolality glutaraldehydeformaldehyde fixative compared to glutaraldehyde. Tissue Cell, 29(5):533-47, 1997.

Eisenback, J. D. A Comparison of Techniques Useful for Preparing Nematodes for Scanning Electron Microscopy. J. Nematol., 18(4):479-87, 1986.

Osborne, M. P. \& Comis, S. D. Preparation of inner ear sensory hair bundles for high resolution scanning electron microscopy. Scanning Microsc., 5(2):555-64, 1991.

Penttila, A.; Kalimo, H. \& Trump, B. F. Influence of glutaraldehyde and/or osmium tetroxide on cell volume, ion content, mechanical stability, and membrane permeability of ehrlich ascites tumor cells. J. Cell Biol., 63(1):197-214, 1974.

Schook, P. The effective osmotic pressure of the fixative for transmission and scanning electron microscopy. Acta Morphol. Neerl. Scand., 18(1):31-45, 1980.

Schraufnagel, D. E. \& Schmid, A. Microvascular casting of 
GUERRERO, F.; CERUTTI, P. \& MARCACCINI, A. Preservation of haemal nodes fixed by means of two different aldehyde fixatives: a scanning electron microscopic study. Int. J. Morphol., 29(2):656-660, 2011.

the lung: effects of various fixation protocols. J. Electron. Microsc. Tech., 8(2):185-91, 1988.

Stoffel, M. H.; Frethem, C.; Hamilton, D. W. \& Friess, A. E. Improved preservation of rat epididymal sperm for highresolution low-voltage scanning electron microscopy (HR-LVSEM). Mol. Reprod. Dev., 34(2):175-82, 1993.

Turner, D. R. The reticulo-endothelial components of the haemal node. A light and electron microscopic study. $J$. Anat., 108(Pt 1):13-22, 1971.

Virtanen, J.; Uusitalo; H.; Palkama, A. \& Kaufman, H. The effect of fixation on corneal endothelial cell dimensions and morphology in scanning electron microscopy. Acta Ophthalmol.(Copenh.), 62(4):577-85, 1984.
Correspondence to:

Dra. Florentina Guerrero

Departamento de Anatomía y Producción Animal.

Facultad de Veterinaria

Universidad de Santiago de Compostela

ESPAÑA

Tel.: +34 982 252231; fax: +34 982252195

Email: florentina.guerrero@usc.es

Received:11-01-2011

Accepted:06-04-2011 